\title{
A collaborative design studio approach to safeguard waterfront resilience in Auckland, Aotearoa New Zealand
}

\author{
Lucia C. M ELCHIORS, Unitec Institute of Technology, New Zealand \\ Xinxin WANG, Unitec Institute of Technology, New Zealand \\ Matthew BRADBURY, Unitec Institute of Technology, New Zealand
}

\begin{abstract}
This paper discusses the potential of an interdisciplinary design studio to develop innovative thinking in response to the climatic and social challenges facing contemporary waterfront redevelopments. Climate change has a broad and growing range of environmental effects on coastal cities that demand urgent responses. The paper describes the development of a collaborative and interdisciplinary design studio that identified a number of design responses to meet the challenges of climate change. The studio brought together students and lecturers from architecture and landscape architecture along with relevant stakeholders (government agencies, practitioners, community) to collaborate on the redevelopment of the Onehunga Port in Auckland, Aotearoa New Zealand. Engagement with mana whenua (the indigenous people of specific areas of Aotearoa New Zealand) was critical. The students worked in teams to conduct critical research and design throughout a masterplanning design process. The outcomes of the studio included openended and propositional designs rather than the conventional masterplans. Students design work addressed complex problems, such as sea-level rise, to develop a more resilient urban future. Beyond the immediate objectives of the studio, the interdisciplinary collaboration demonstrated a range of benefits, including students learning to work in teams, sharing complementary views, broadening perspectives and increasing social awareness.
\end{abstract}

\section{Keywords}

Collaboration; interdisciplinary design studio; resilience; climate change; waterfront; design education.

\section{Introduction}

The environmental effects of climate change pose a growing challenge to the viability of urban spaces located in coastal areas (Intergovernmental Panel on Climate Change, 2014). Aotearoa New Zealand, an island nation, is already feeling the effects of climate change and these effects only are expected to intensify in the future, especially sea level rising and more frequent storms (Shuster et al., 2005). In this context, the design of resilient waterfronts that specifically address these problems is vital for the creation of sustainable post-industrial waterfronts (Breen and Rigby, 1996). 
This paper discusses the potential of an interdisciplinary design studio to develop innovative thinking in response to the climatic and social challenges associated with the development of the urban waterfront. Using a case study, the paper describes a collaborative approach to teaching practice. The studio project uses a specific framework to help build collaboration and to expose students to real-world problems. This process demonstrates how an interdisciplinary learning space can contribute to shape the development of a more resilient urban future. The redevelopment of the Onehunga Port, in Auckland, was an opportunity to test the studio approach. The project involved the participation of students and a multiplicity of stakeholders, drawn from government agencies, practitioners, the community and mana whenua (the indigenous people of specific areas of Aotearoa New Zealand). Architecture and landscape architecture students worked in teams with the owners of the site, a local government agency (Panuku) to conduct critical research and design throughout a masterplanning design process.

The paper is organized into six parts. The first part sets out the importance of designing resilient waterfronts to address the impact of climate change. The interdisciplinary collaborative studio model developed to test these ideas is then explained, including the theoretical approach and the process organization. The Onehunga waterfront is presented as the case study to demonstrate how the studio process was used in the re-design of an urban waterfront. The findings of the design work, how students incorporated adaptive design strategies to help create a more resilient future for coastal urban areas, are then analysed and discussed. Finally, the advantages of the adoption of an interdisciplinary collaboration design process are considered gains beyond the project's immediate objectives.

\section{Why coastal/ waterfront resilience matters?}

The environmental effects caused by climate change pose a number of challenges to the planning of coastal urban areas. The environmental impact of climate change on coastal areas will not only be caused by the rising sea level and more frequent storm surges but also from pluvial flooding from the wider inland catchment. Considering these risks, urban coastal cities needs to be made more resilient to adapt to the effects of climate, by creating a more sustainable development.

The tradition definition of resilience refers to the ability to bounce back to original status (Folke, 2006). Resilience theory helps people to understand the complexity of ecological and social systems and the management of these systems in a sustainable way, especially in response to the changing climate (Meerow, Newell and Stults, 2016). Current resilience strategies are categorized as a spectrum ranging from "coping" through to "incremental adaptation", and "transformational adaptation" (Torabi, Dedekorkut-Howes and Howes, 2018). In the context of climate change, resilience usually refers to the ability to recover from more frequent natural disasters (Hill and Kakenmaster, 2018).

Some design strategies can be used for increasing coastal resilience to the effects of climate change. $M$ apping risk and assessing the impact on human and natural communities is critical. Scientific studies can be used to identify areas vulnerable to future climate change, especially those in danger of sea-level rise, and the consequent potential damage to human communities and the natural environment. Researchers and practitioners have explored the use of Geographical Information systems software ( GIS) to both map and simulate the long-term effects of climate change on coastal communities (Idowu and Home, 2015; Neumann et al., 2015; Allen et al., 2016; Meerow, Newell and Stults, 2016; Thead, 2016). Strategies to address these effects can start with integrating green infrastructure or natural solutions with existing grey infrastructure, such as sea walls and levees to increase habitat resilience and mitigate stormwater flooding to increase coastal resilience (Nordenson and Seavitt, 2015) (Carney, 2017; O'Donnell, 2017; Wesener et al., 2017; Antunes do Carmo, 2018; Almarshed, 2020). These integrated solutions can enhance coastal defence and mitigate flooding from the surrounding catchment by allow certain areas to be flooded in a safe and controllable way.

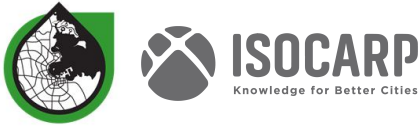


Taking community engagement into the centre of climate change design is vital to successfully implement resilience plans at the local scale. Keeping close engagement with coastal communities can give the design team an in-depth understanding of the economic, social, and cultural issues beyond technical mapping. This engagement can help broaden the community's scope for addressing the impact of climate change and to help prepare them for disaster response and to offer them alternative solutions for future sustainable development (Allen et al., 2016; Carney, 2017; Bradbury et al., 2018; Wang et al., 2018).

New Zealand, a small island nation in the Pacific Ocean with much of its urban settlement on the coast, is already facing the effects of climate change (M FE, 2014). Considering ways to build resilience to sea level rise and pluvial flooding for New Zealand cities is becoming increasingly necessary. The studio model described below investigates the design of resilient coastal zones.

\section{Designing the studio model}

The studio employs a collaborative and interdisciplinary learning approach. The project was developed as a joint course, during a semester, integrating architecture (3rd year) and landscape architecture students (4th year) at the School of Architecture, Unitec, Auckland, New Zealand. During this process, students worked on open ended projects in an active practice model that provokes them to take the initiative in their learning process. The students were encouraged to think critically and develop their own ideas about complex issues related to urban design and resilient strategies. The studio project aimed to engage students with the typical problems that are related to the redevelopment of an urban waterfront. These problems range from respecting the local community's aspirations to proposing innovative design solutions to the effects of climate change at various territorial scales.

\subsection{Studio approach}

The studio framework, is based on three key themes:

1. Research by design and a design process that is influenced by ecological analysis

2. Collaboration and interdisciplinarity, integrating disciplines, students and community;

3. Acknowledgment of the mana whenua (Maori iwi) specific to the location through a respect for indigenous values.

Research by design and a design process articulated to a method of ecological analysis

The methodology of this studio is based on research by design. This methodology uses design not only as a result, but as an investigation process, through the development of a project (Verbeke, 2011; Rosa et al., 2014). In this process, design is a method of inquiry (an instrument to generate and test ideas) and a result (used to communicate propositions) (Hauberg, 2011; Verbeke, 2011; Rosa et al., 2014; Roggema, 2017). Through the exploration of different techniques (sketching, mappings, videos, technical drawings, among others), design is used as an active representation of cognitive processes that help to visualise things in a different way than achieved by using words (Hauberg, 2011). Many theorists in the field identify the value of research by design for creative disciplines and to address future speculative problems (Hauberg, 2011; Verbeke, 2011; Rosa et al., 2014; Roggema, 2017).

According to Roggema (2016), research by design projects shares three characteristics: a) the project should be embedded in the local, cultural and political context; b) the project should allow for unexpected exploration in order to identify the best-fitting solutions for a design problem; c) the project should emphasise the development of new knowledge and be beneficial to a broad public.

Geographic Information System (GIS) helps in the analysis and design of data, especially environmental data (Schuurman, 2004). GIS can be used to map a catchment and to analyse the hydrological pattern. 
Using a digital model of the site, the hydrological behaviour and pattern of a landscape catchment can also be modelled (Shamsi, 2005). ArcGIS (ESRI) software, the original Digital Elevation M odel DEM data can be integrated with hydrological information to determine the boundaries of a catchment network on any given terrain. The modelling can also show the effects of an increase in rainfall and the effects of a lessening or increase in perviousness of the different surfaces in the catchment (Skidmore, 2002).

\section{Collaboration and interdisciplinarity: integrating students, disciplines and community}

This multi-disciplinary approach started with the integration of architecture and landscape architecture students. By combining students of architecture and landscape architecture and integrating them with community representatives throughout the process, students were connected closer to the real-world of design practice.

Collaborative and multidisciplinary learning is used to refer to methods that encourage and require students to work collectively on learning tasks, which are relevant for cognitive learning and students' social and emotional development. (De Hei et al., 2015; Neuman, 2018). This approach encourages students to learn non-routine perspectives and promotes cultural exchange and an appreciation of diversity through sharing different design perspectives, learning new approaches and techniques (Hirt and Luescher, 2007; Kim, Ju and Lee, 2015). In this process, knowledge is socially constructed, through a learning process that occurs via conversations, collaboration and constructive conflicts. A multidisciplinary experience complements students' experiences and skills to deal with complex urban problems that require a disciplinary mix of competencies (Hirt and Luescher, 2007; De Hei et al., 2015; Kim, Ju and Lee, 2015; Neuman, 2018).

The designs studio promoted a deliberate engagement with a multiplicity of stakeholders, drawn from government agencies, practitioners, community and Mana whenua (the indigenous people of specific locations in New Zealand/Aotearoa). Working in teams through a process of site investigation, discussion, presentation and critique, students gained valuable experience in developing research and design ideas with clients. Students connect with stakeholders not just in studio but in site visits, critique discussions and presentations. Guest critics from the community, architects, urban designers and other practitioners provide important feedback for students to examine their ideas.

Acknowledgement of the mana whenua as central responsibility for design practice in Aotearoa New Zealand

In Aotearoa/New Zealand all citizens, Māori and Tuaiwi, have specific obligation under the Treaty of Waitangi (Orange, 2015). Māori have a right to equally participation in any decision making in the public realm. Matauranga Māori (Maori knowledge) can help to shape the environmental processes that lead to building a more resilient waterfront. The design studio advocated the uses of the Te Aranga Design Principles. The Auckland Design M anual describes the Te Aranga Design Principles as "set of outcome-based principles founded on intrinsic Māori cultural values and designed to provide practical guidance for enhancing outcomes for the design environment. The principles have arisen from a widely held desire to enhance mana whenua presence, visibility and participation in the design of the physical realm" (Auckland Design $M$ anual, 2016). The principles provide directions to positively engage with $M$ ana Whenua aiming to shape a built environment that acknowledge the local values. At the same time, they contribute to the promotion of local indigenous values, highlighting Aotearoa's unique cultural context and identity.

\subsection{Studio process}

The design studio was organized into three phases. The first started with a research, developed over 3 weeks. Students produced a report investigating relevant case studies, analysing the site through GIS mapping and identifying appropriate strategies to increase environmental resilience. In the second phase, lasting 3 weeks, each multidisciplinary group of students created a masterplan based on the research 


\section{A collaborative design studio approach to safeguard Melchiors, L. C; Wang, X.; Bradbury, M. waterfront resilience in Auckland, New Zealand/ Aotearoa}

report. The masterplan explored design solutions that responded to the challenge of climate change, connections with the context and recognition of Mana Whenua. In the last phase, students worked individually in discipline specific project to design a public space or a mixed-use building with 4-6 floors.

The studio design process was conducted by combining several pedagogical techniques, including discussion in the studio (the main component of the learning process, where students share research, perceptions and assessments); lectures and informal talks with experts (to develop student knowledge); informal pin-ups (aiming to create a collaborative learning environment, where students can share and discuss ideas during the process); site visits and lastly critiques, including those from the community to inform decisions and help assess students.

\section{Case study: Onehunga project}

The Onehunga Port, Auckland, New Zealand was chosen as the case study site. The port will be affected by climate change, including sea level rise and flooding from a large impervious urban catchment (Liu, Goonetilleke and Egodawatta, 2015).

\section{Background}

The Onehunga Port was bought by Panuku, the Auckland Council development agency (Panuku Development Auckland, 2017), as part of a strategy to revitalize the Onehunga neighbourhood. Working with Panuku, Unitec developed a design project for the joint Landscape / Architecture studio. The brief proposed a waterfront development model that built resilience to the environmental depredation that will be caused by climate change, especially the effects of sea level rise and pluvial flooding. The studio project also aimed commercial returns and enhance the connections with the Onehunga township and the context. Recognizing Mana whenua and the site's rich historical, cultural and landscape features was a critical part of the brief.

The site

The 6ha site (Figure 1) is an industrial port and an active fish processing plant located in Onehunga neighbourhood. The port is situated between Te Hopua a Rangi (an extinct volcano) and the edge of $M$ anukau Harbour. The site is easily accessed from State Highway 20 enabling a connection to the CBD and the airport. However, $\mathrm{SH} 20$ also acts as a barrier, isolating the port from the Onehunga township. The site is part of Auckland's volcanic field - with Maungakiekie to the north, Te Pane o M ataaho to the south, Te Tatua-o-Riukiuta to the west and Rarotonga to the east. The area has historical and cultural significance. Onehunga bay was used as a trade centre for Māori, many of the iwi (tribes) associated with Tamaki M akaurau (Auckland) have a connection to the area (Auckland Council, 2010). European settlement began in 1835 , trading with Maori. The port started to be developed in the early 20 th century, built on reclaimed land at the of Te Hopua. 


\section{A collaborative design studio approach to safeguard waterfront resilience in Auckland, New Zealand/ Aotearoa}
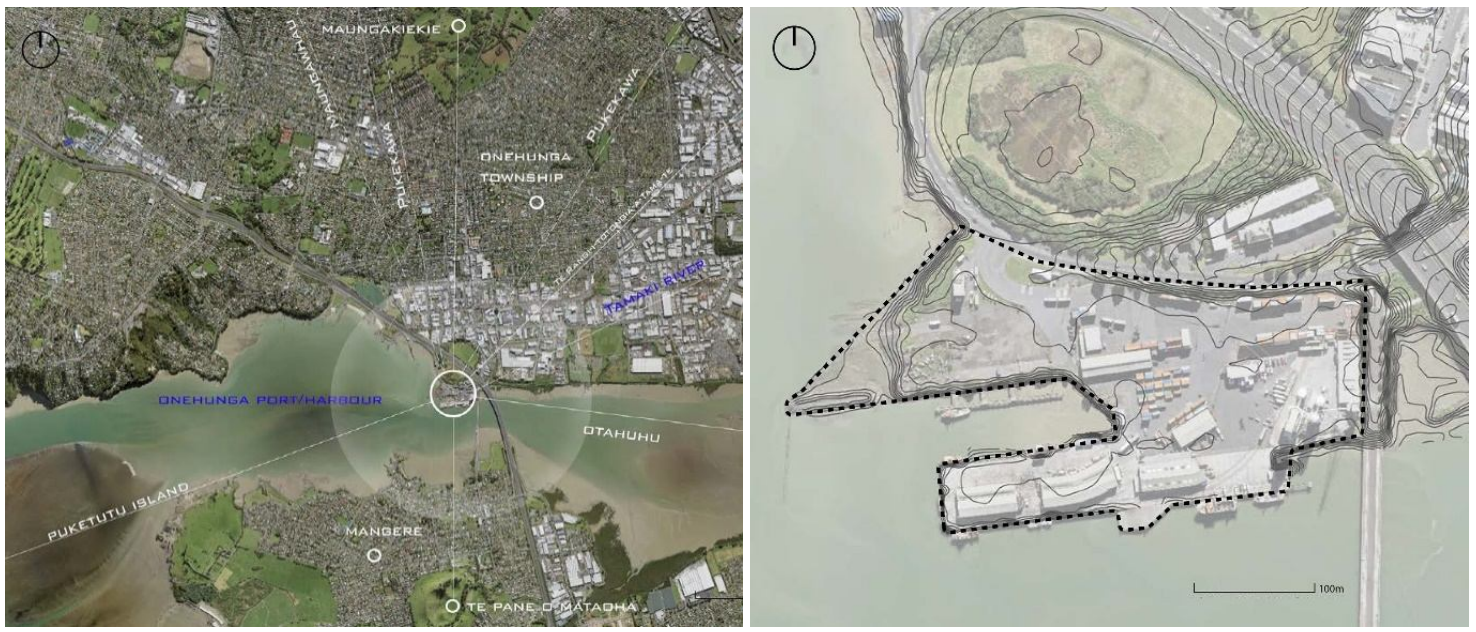

Figure 1. Onehunga port: wilder context and site in detail. Image credit: Nicholas Fortier, Christian Castle, Dilukshi Thurairajah, Xuling Zhu, Benjamin Whitehouse.

\section{The Onehunga port studio - collaborative process}

Collaboration was an important method emphasised in the structuring of the project. Complementing the interdisciplinarity of students and teachers, a multiplicity of stakeholders was involved in the process. Site visits were led by the port owner, Panuku, around the key features and issues on the Onehunga port. Students also investigated the structure and history of the Onehunga town centre, to better understand the context and aspirations of the community. Students met with a representative of mana whenua, Amiria Puia-Taylor, director of 312 Hub (a social enterprise based that works with educational and artistic projects in the community) (Figure 2). Lectures and discussions with Māori landscape architect, Alan Titchener (founding member of Ngā Aho, a collective of Māori design professionals and co-ordinator of Māori landscape architects), helped students to connect Mātauranga Māori (Māori knowledge) with design practice. During the semester, students also engaged with architects, urban designers and landscape architects receiving important feedback on their work.
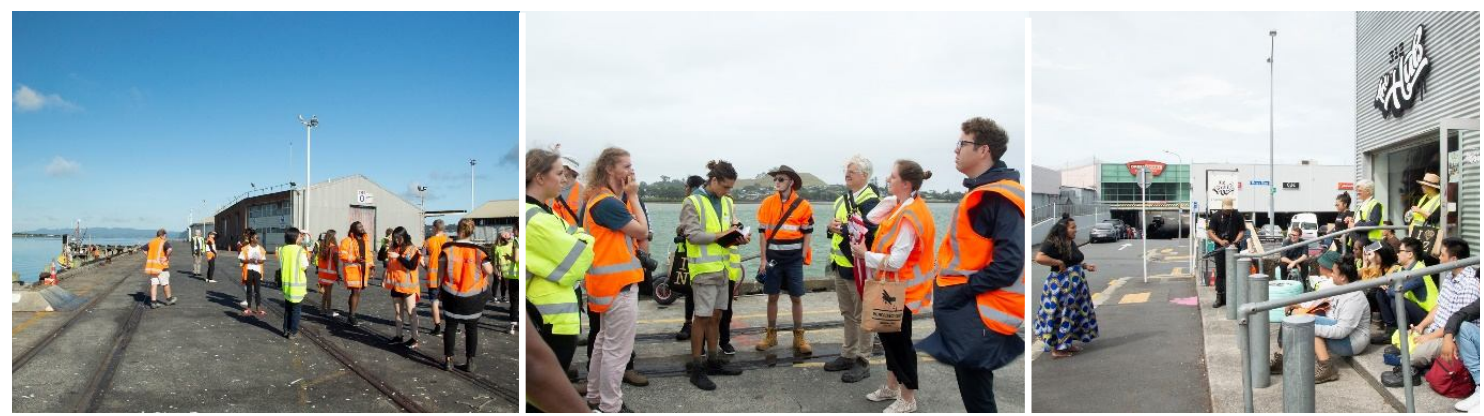

Figure 2. Site visit included conversations with Panuku members and Mãori representatives of Onehunga community. Image credit: Lucia M elchiors.

\section{Waterfront adaptive design strategies}

Students explored several climate change proofing adaptive strategies and evaluated their applicability in response to the flood events. Design strategies to ensure buildings were protected from flooding included solutions such as; elevating buildings on fill or piles and amphibious structures. Design strategies for landscape protection included; hard engineering solutions such as bulkheads and levees, soft green infrastructures such as wetlands and swales, and integrated green-grey infrastructures like living shorelines and raised parks. Figure 3 shows examples of some of these strategies. 
A collaborative design studio approach to safeguard Melchiors, L. C; Wang, X.; Bradbury, M. waterfront resilience in Auckland, New Zealand/ Aotearoa

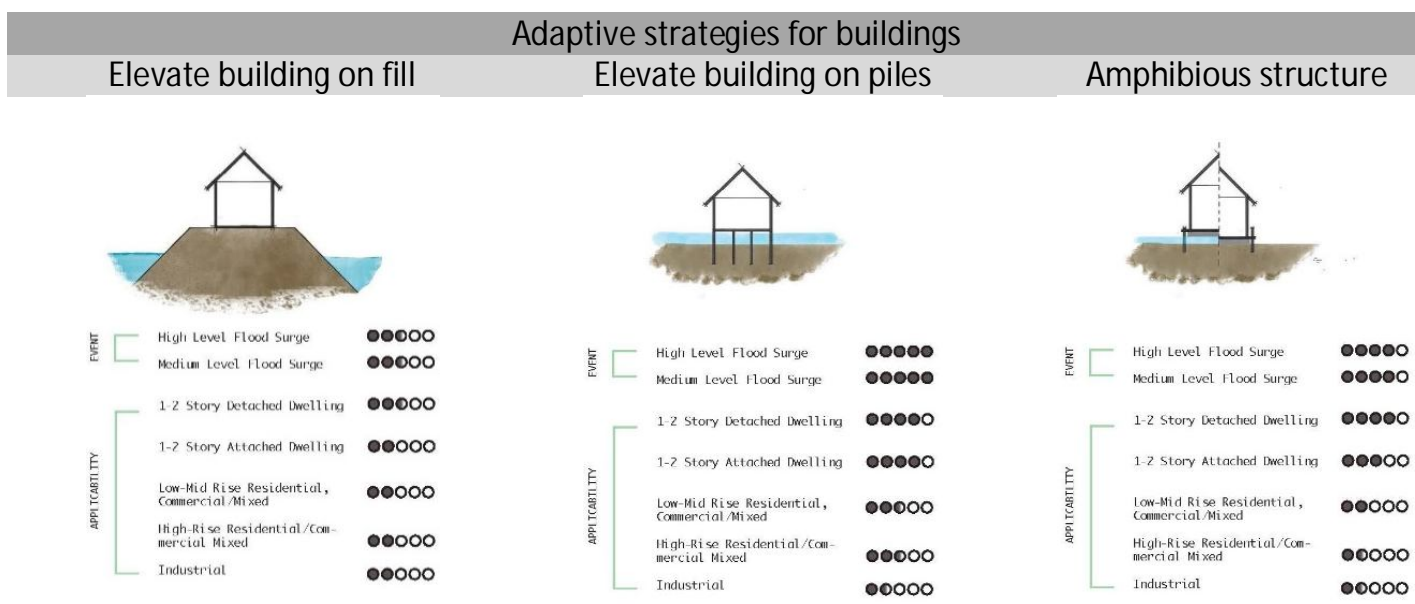

Elevation of land and streets

Adaptive strategies for landscape Raised waterfront parks

Living shorelines
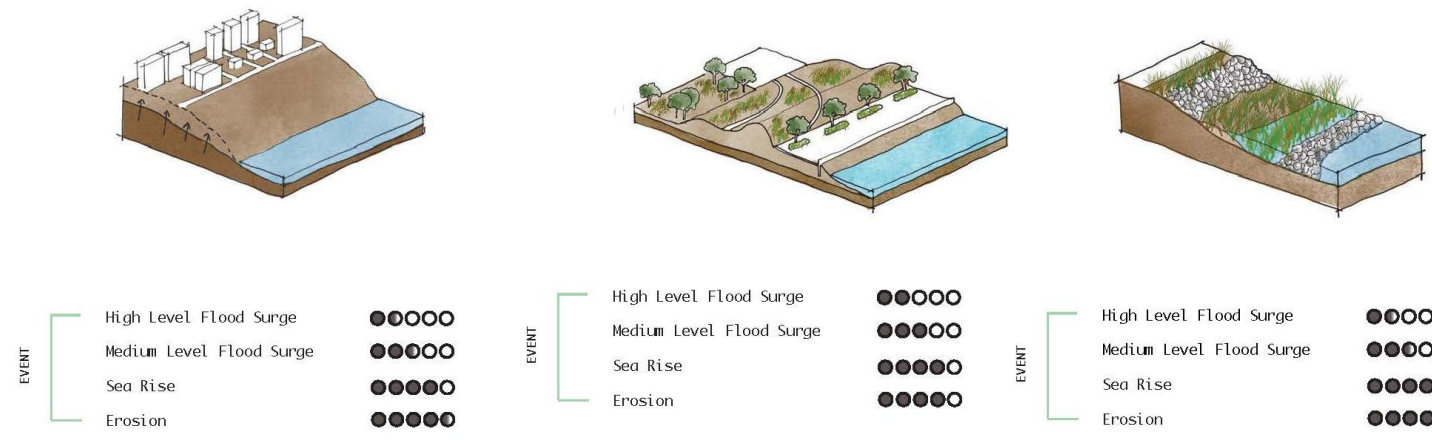

00000

00000

00000

0000

Figure 3. Adaptive strategies for buildings and landscape studied by students. Images adapted from (Department of City Planning City of New York, 2013). Analysis from students: Trina Gaston, Rory Gray, Torben Laubscher, Thomas Smith.

\section{Onehunga Port project: climate adaptation and collaborative design}

The Onehunga Port project found that open-ended and propositional design strategies were more responsive to the environmental challenges of climate change than the conventional masterplan model. The collaboration between the design disciplines, landscape and architecture, also helped to make the design decisions more nuanced and responsive.

Students proposed a number of design explorations that addressed complex problems, such as the impact of on sea-level rise on the Onehunga Port. A simulation of sea-level rise for the site showed that the impact of a one-meter rise would inundate most of the port. A two-meter rise would cover the entire site. Responding to these challenges, students designed a green-blue strategy including:

- coastal wetland parks to improve the ratio of pervious surface to help absorb runoff, restore local ecology and introducing native species to mitigate flooding,

- embracing the sea level rise by using tidal pools and floodable landscapes,

- partially raising of parts of the site to avoid flooding,

- designing sky garden/highline strategies to help integrate buildings and landscape.

\section{Coastal wetland parks}

Coastal wetland parks were used as a key strategy by many groups. Students explored the different functions that can be offer by wetlands: not only to store and mitigate stormwater flooding from the 
Onehunga catchment, but also to restore the marine ecology in the intertidal zone and provide new social opportunities for local residents (Figure 4).

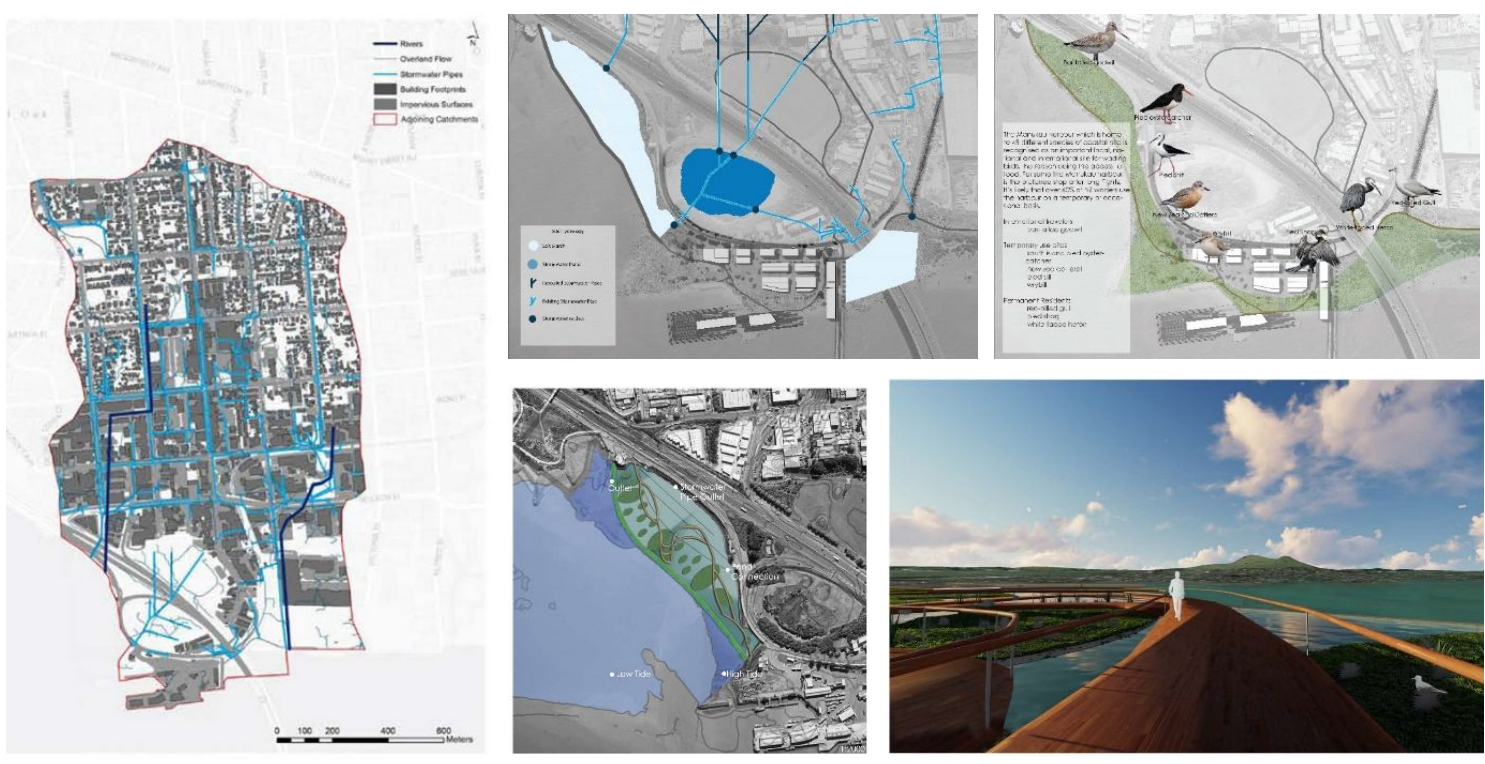

Figure 4. The first image shows the stormwater catchment and overland flow paths from the Onehunga catchment. The top images demonstrate the development of a coastal salt marsh. Image credit: Anton Jones, Katherine Knight, Alex Sames, Sabina Becic, Sade Carlile-Ponga. The bottom images illustrate the development of a coastal wetland and elevated board walk. Image credit: Anton Jones.

\section{Embracing the flood: tidal pools and floodable landscape}

The Hinekirikiri project (intertidal zone) is an example of a project that creates a resilient landscape that embraces the rising sea level. Figure 5 shows how students accepted the flooding of the site over the years, proposing a different design response for each situation.

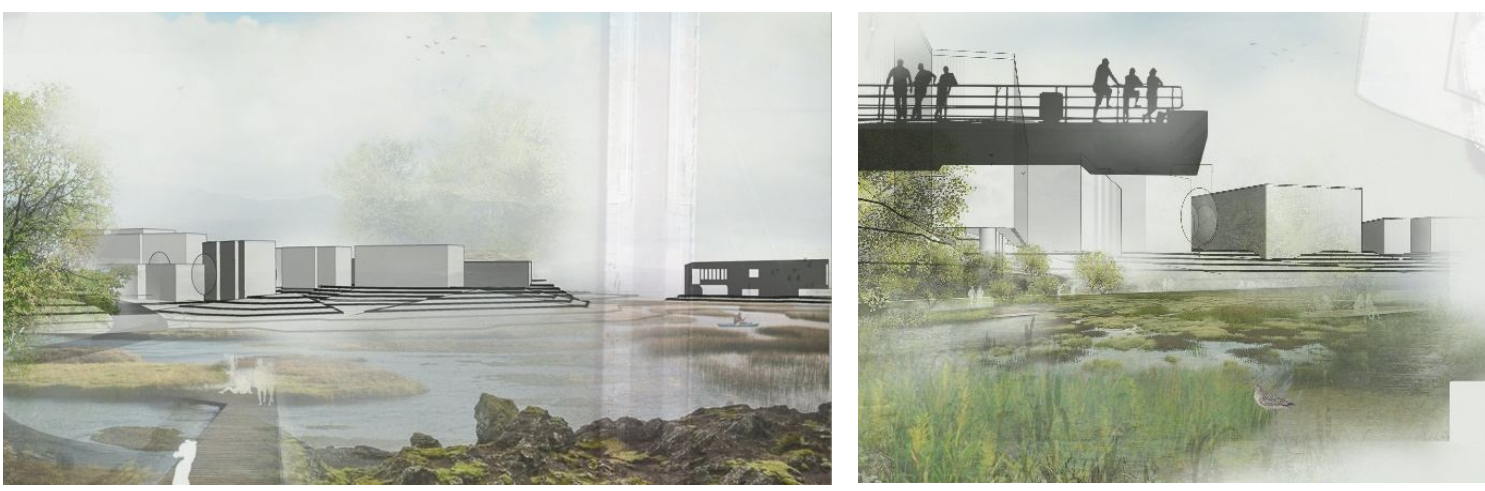

Figure 5. Intertidal zone creating a resilient landscape that embraces the rising sea level. Image credit: James Anderson, Victoria M canulty, Kirrily Poliko, Jennifer Wu, Princeton M otupalli.

Some students studied how public spaces could be adapted to allow for flooding. These design strategies fully acknowledged the dynamics of tidal change and seriously considered the potential impact of future sea level rise. Figure 6 shows a proposed a staged design response to the future changing water levels. Through a carefully considered grading plan and selection of native plants, the proposed design outcome offered the Onehunga community a safe and adaptable environment. Public space design was integrated with a staged retreat from sea level rise, to ensure both public safety and yet ensure a continued intimacy with the water line. 

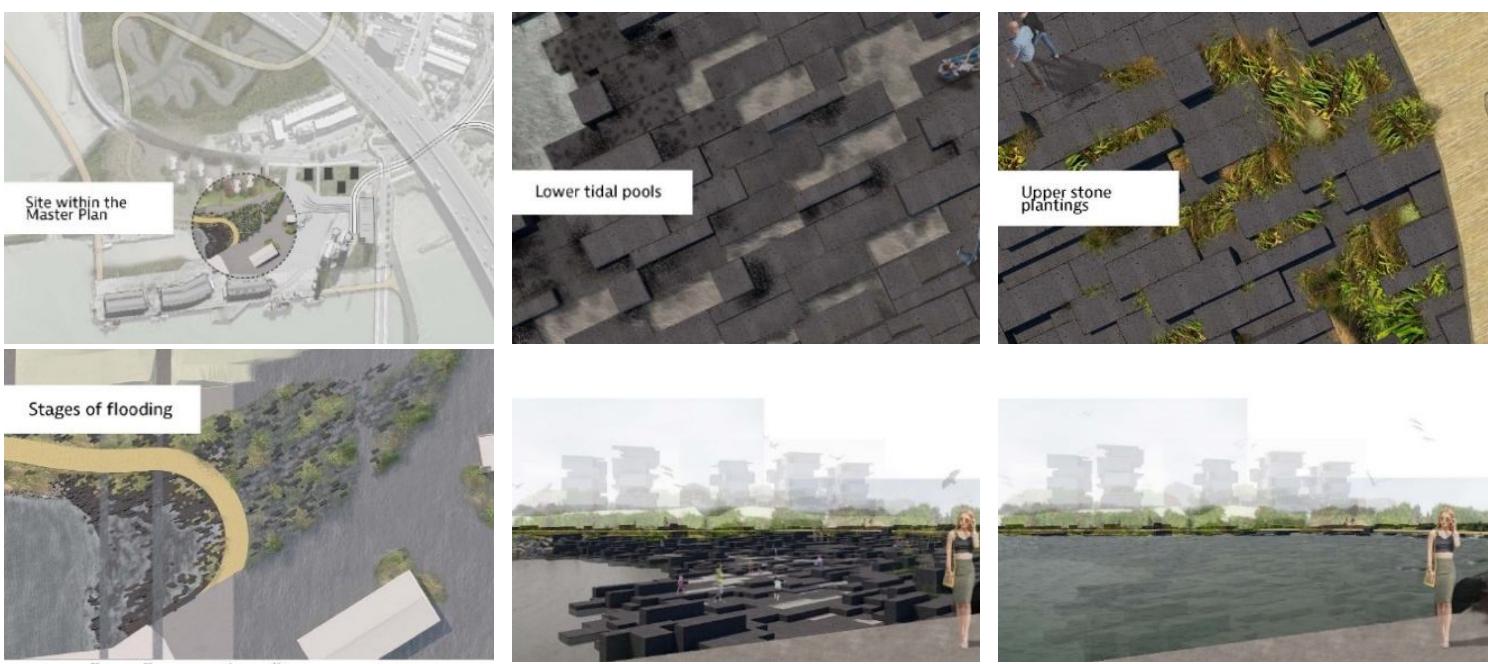

Figure 6. Living shoreline and a floodable landscape made up of basaltic paving with gaps for the planting of careful gradient of native coastal plants from a typical Auckland coastal eco tone. Images show the dry and flooding condition of the new coastal edges. Image credit: Nickolas Fortier.

\section{Raising the land: designing an elevated terrain and streets}

Figure 7 shows a design proposal that mixes the strategy of elevated land and streets and allowing for a sacrificial zone, a floodable landscape in other parts of the site to accommodate sea level rise. The image demonstrates how the site will be changed over the time according to the increase in the sea level. These students raised the northern part of the site to provide a dry building platform for Panuku's new residential buildings programme. The land between the new buildings and the sea was terraced to mimic a volcanic lava flow (emphasizing the historic volcanic character of the site). Floating walking and cycling paths were proposed to link to the remaining site, allowing residents to explore the old structures on the wharf, as well as connecting to Te Hopua and Onehunga township.
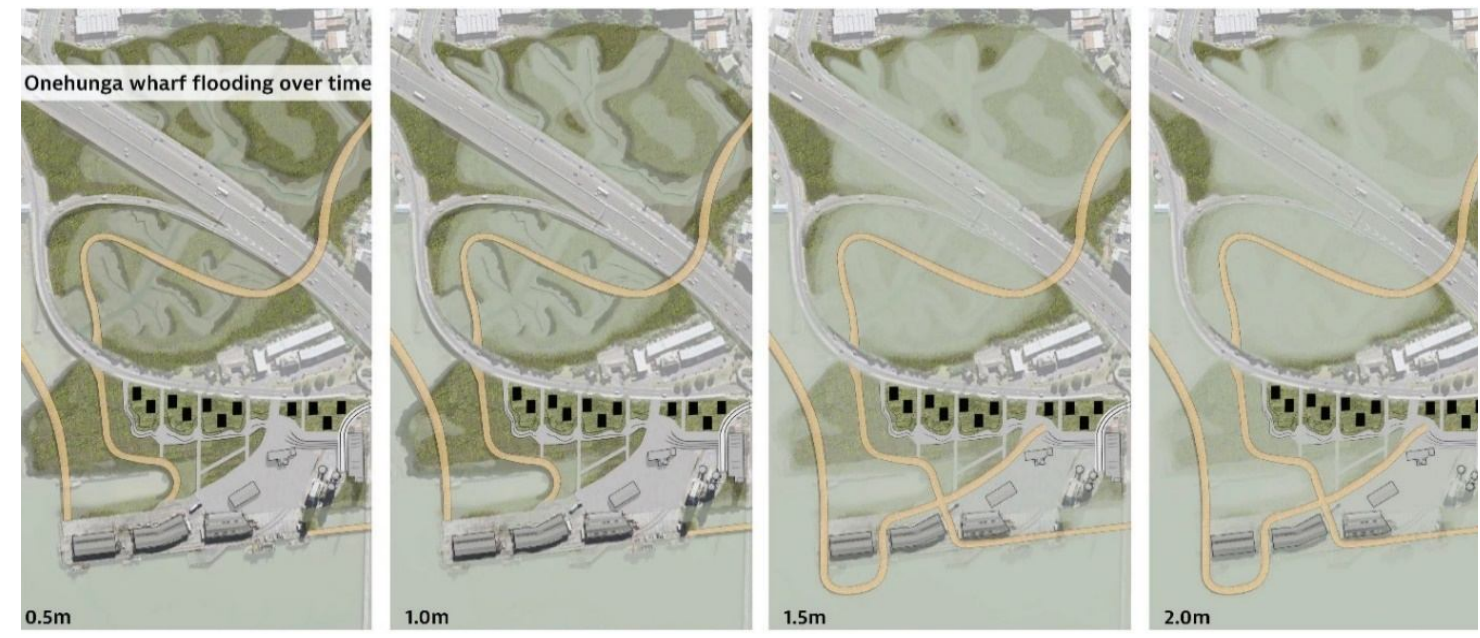

Figure 7. Staged retreat and floodable landscape in response to the rising sea levels. Image credit: Nicholas Fortier, Christian Castle, Dilukshi Thurairajah, Xuling Zhu, Benjamin Whitehouse

A number of architecture and landscape students kept working in collaboration throughout the detailed design phase. This enabled them to continue to adjust their building and landscape project to complement one another. Architecture design decisions such as the placement and orientation of buildings, were informed by landscape consideration such as the grading of landforms, the provision of view shaft to the 
surrounding maunga and the transition from private to public space. Landscape projects were also influenced by the proximity to the building programme, with issues such as the location of entries and the shade created by the building height. The Figure 8 exemplifies this process. The orientation of apartment buildings was discussed by landscape architects and architects. This resulted in the careful siting of the apartment to allow for north-south view shafts to connect with tot he is surrounding Auckland maunga (volcanos). The landscape architect designed the raised building platform to allow for a topographic mediation between the building terrace and the flood plain. The building used a solar orientation analysis to carefully place the apartments, allowing for harbour view for most residents. A permeable ground plain created a fluent transition between the indoor spaces and the grass terraces.
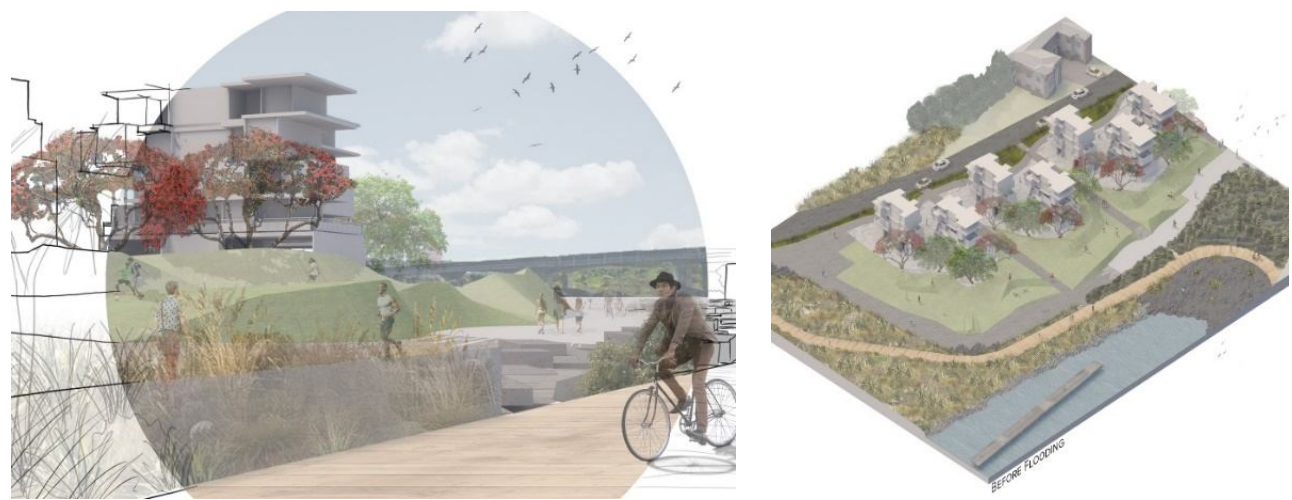

Figure 8. Integrated landscape and architecture with a fluid topography. Image credit: Christian Castle and Dilukshi Thurairajah.

\section{Sky garden/ highline}

Elevated gardens or parks were also considered by some students demonstrating a strong connection between landscape and architecture disciplines. The sky gardens were located at different levels and help play an important role in keeping recreational activities above the future flood zone. The Figure 9 illustrate a project where the strategy was used incorporated to the re-use of the existing industrial silos. In this project, the elevated gardens also act as links to enhance the connection around the site and bring together the wide communities of Onehunga and Mangere.

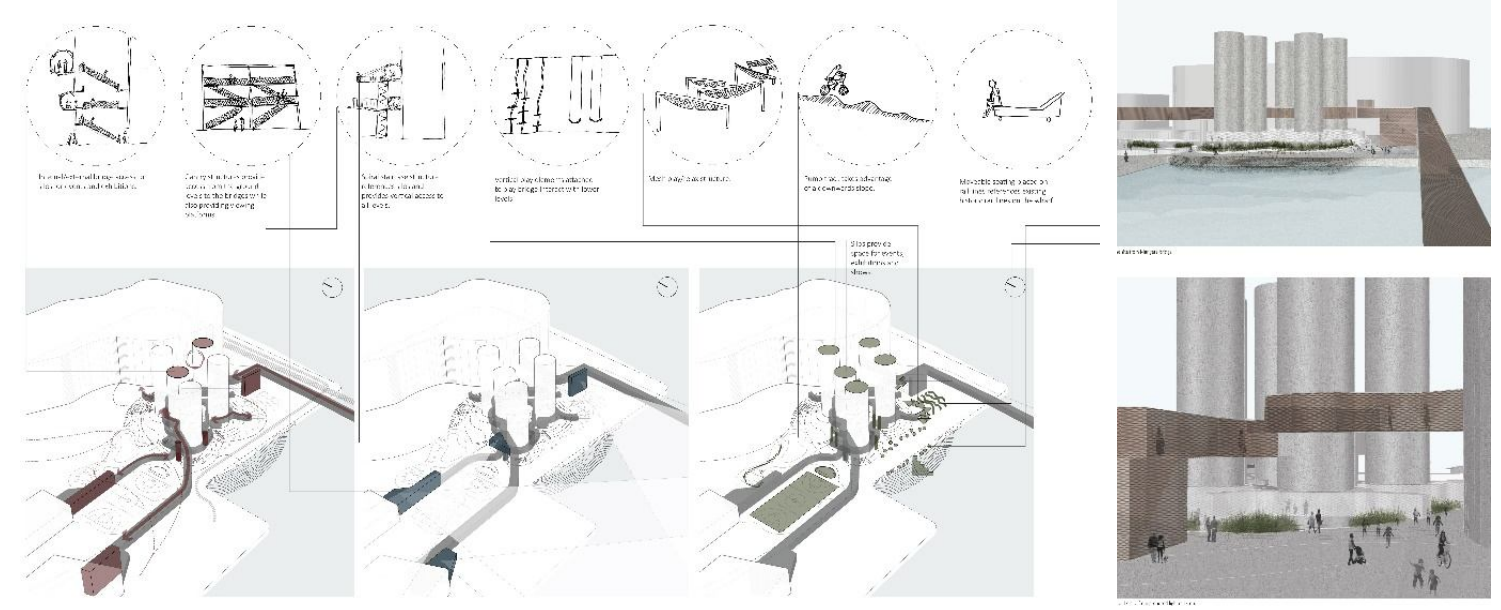

Figure 9. Sky gardens around the existing silo. Image credit: Kelsey Stankovich. 


\section{Conclusion}

This paper discussed the potential of a collaborative design studio to develop innovative thinking in response to the environmental effects of climate change facing contemporary waterfront redevelopments. Interdisciplinary collaboration, as a teaching-learning method, give students an opportunity to engage with stakeholders while reflecting on environmental and social issues.

Beyond the immediate goals of the studio, the interdisciplinary collaboration demonstrated a number of advantages; among them, students learned to work in teams, sharing complementary views and broadening perspective. The collaboration between architecture and landscape students provided an experience close to that the professional world. The process also prepared students to become citizens with increased social awareness. Working collaboratively can encourage students to go beyond developing a conventional design concept, think critically, seek innovation and develop their own ideas about real and complex issues related to urban design, culture, ecology and resilient urban spaces. The generous participation of mana whenua in sharing $M$ atauranga $M$ aori helped students to understand how to address their obligation under Te Tiriti. While the focus of the project was to address climatic and social issues in Aotearoa New Zealand, the collaborative learning design approach, with adaptations, can be applied to other urban areas. The interdisciplinary collaboration described in this article offers good insights into addressing complex urban and environmental issues in a landscape/ architectural studio context.

\section{References}

Allen, L. et al. (2016) 'Design for resilience', NZSEE Conference, p. 9.

Almarshed, B. (2020) 'Innovative coastal risk reduction through hybrid design: Combining sand cover and structural defenses', Journal of Coastal Research, 36(1), pp. 174-188.

Antunes do Carmo, J. S. (2018) 'Climate change, adaptation measures, and integrated coastal zone management: The new protection paradigm for the Portuguese coastal zone', Journal of Coastal Research, 34(3), pp. 687-703.

Auckland Council (2010) The hapū and iwi of Tāmaki Makaurau [Online"]. Available at: https:// www.aucklandcouncil.govt.nz/ plans-projects-policies-reports-bylaws/our-plans-strategies/ aucklandplan/about-the-auckland-plan/Pages/iwi-tamaki-makaurau.aspx.

Auckland Design Manual (2016) Te Aranga Principles. Available at: http://www.aucklanddesignmanual.co.nz/design-subjects/maori-design/te_aranga_principles.

Bradbury, M. et al. (2018) The Hihiaua Studio. Auckland, New Zealand: ePress. Available at: https://www.unitec.ac.nz/ epress/index.php/the-hihiaua-studio/.

Breen, A. and Rigby, D. (1996) The New Waterfront : A worldwide urban success story. London: Thames and Hudson.

Carney, J. (2017) 'The design of resilient coastal communities and ecosystems responding to climate changes', Landscape Architecture Frontiers. Editorial Department of Engineering Sciences, 5(4), p. 44. doi: 10.15302/j-laf20170406.

Department of City Planning City of New York (2013) Coastal climate resilience: Urban waterfront adaptative strategies.

Folke, C. (2006) 'Resilience: The emergence of a perspective for social-ecological systems analyses', Global Environmental Change, 16, pp. 253-267.

Hauberg, J. (2011) 'Research by Design - a research strategy: Conference Bruxelles'.

De Hei, M. S. A. et al. (2015) 'Collaborative learning in higher education: lecturers' practices and beliefs', Research Papers in Education, 30(2), pp. 232-247. doi: 10.1080/02671522.2014.908407. 


\section{A collaborative design studio approach to safeguard Melchiors, L. C; Wang, X.; Bradbury, M. waterfront resilience in Auckland, New Zealand/ Aotearoa}

Hill, A. C. and Kakenmaster, W. (2018) 'An overview of "resilience" and climate change', Bulletin of the Atomic Scientists. Routledge, 74(2), pp. 61-65. doi: 10.1080/00963402.2018.1436803.

Hirt, S. and Luescher, A. (2007) 'Collaboration between architects and planners in an urban design studio: potential for interdisciplinary learning', Journal of Design Research, 6(4), pp. 422-443. doi: 10.1504/JDR.2007.016852.

Idowu, T. E. and Home, P. G. (2015) 'Probable effects of sea level rise and land reclamation activities on coastlines and wetlands', The 2015 JKUAT Scientific Conference, (November), pp. 207-220.

Intergovernmental Panel on Climate Change (2014) Climate Change 2014 Synthesis Report, Summary for Policymakers Chapter.

Kim, M. J., Ju, S. R. and Lee, L. (2015) 'A cross-cultural and interdisciplinary collaboration in a joint design studio', International Journal of Art and Design Education, 34(1), pp. 102-120. doi: 10.1111/jade.12019.

Liu, A., Goonetilleke, A. and Egodawatta, P. (2015) Role of Rainfall and Catchment Characteristics on Urban Stormwater Quality. Singapore: Springer.

Meerow, S., Newell, J. P. and Stults, M. (2016) 'Defining urban resilience: A review', Landscape and Urban Planning. Elsevier B.V., 147, pp. 38-49. doi: 10.1016/j.landurbplan.2015.11.011.

M FE (2014) 3 Implications for New Zealand's coastal margins [Online]. Available at:

http://www.mfe.govt.nz/publications/climate-change/coastal-hazards-and-climate-change-guidance-manuallocal-government-n-21 (Accessed: 20 July 2011).

Neuman, M. (2018) 'The Collaborative Interdisciplinary Studio', in Frank, A. and Silver, C. (eds) Urban Planning Education. The Urban Book Series. Springer, Cham. doi: 10.1007/978-3-319-55967-4_18.

Neumann, B. et al. (2015) 'Future Coastal Population Growth and Exposure to Sea-Level Rise and Coastal Flooding - A Global Assessment', PLOS ONE. Public Library of Science, 10(3), pp. 1-34. doi:

10.1371/journal.pone.0118571.

Nordenson, G. and Seavitt, C. (2015) 'Structures of coastal resilience: Designs for climate change', Social Research. Johns Hopkins University Press, 82(3), pp. 655-671.

O'Donnell, J. E. D. (2017) 'Living shorelines: A review of literature relevant to New Engliand coasts', Journal of Coastal Research, 33(2), pp. 435-451.

Orange, C. (2015) The Treaty of Waitangi. Auckland: Bridget Williams Books.

Panuku Development Auckland (2017) Onehunga. Transform Onehunga. High Level Project Plan [Online]. Available at: https://www. panuku.co.nz/ downloads/assets/4838/1/ onehunga high level project plan (part one).pdf.

Roggema, R. (2017) 'Research by Design: Proposition for a Methodological Approach', Urban Science, 1(2). doi: 10.3390/urbansci1010002.

Rosa, E. et al. (2014) 'Design Studio as a Process of Inquiry : The case of Studio Sao Abstract : Research by design', Fourth International Conference on Architectural Research by Design (ARbD'14), (11), pp. 241-254.

Schuurman, N. (2004) GIS: A Short Introduction. Malden, M A: Blackwell.

Shamsi, U. M. (2005) GIS applications for water, wastewater, and stormwater systems. Boca Raton, FL: Taylor \& Francis.

Shuster, W. D. et al. (2005) 'Impacts of impervious surface on watershed hydrology: A review', Urban Water Journal. Taylor \& Francis, 2(4), pp. 263-275. doi: 10.1080/15730620500386529.

Skidmore, A. P. H. (2002) Environmental modelling with GIS and remote sensing. London; New York: Taylor Francis.

Thead, E. A. (2016) Sea level rise: Risk and resilience in coastal cities, A publication of the Climate Institute. Washington. DC.

Torabi, E., Dedekorkut-Howes, A. and Howes, M. (2018) 'Adapting or maladapting: Building resilience to 
A collaborative design studio approach to safeguard

Melchiors, L. C; Wang, X.; Bradbury, M. waterfront resilience in Auckland, New Zealand/ Aotearoa

climate-related disasters in coastal cities', Cities, 72, pp. 295-309. doi: 10.1016/j.cities.2017.09.008.

Verbeke, J. (2011) 'Research by Design is up and running', Architecture \& Education Journal, 5, pp. 109-119.

Wang, X. et al. (2018) 'Collaborative student and community design in a time of Climate Change: Planning a flood-resilient waterfront in New Zealand', ISOCARP Review 14 - Climate Change Planning, 14(1), pp. 38-55.

Wesener, A. et al. (2017) 'Integrated Urban Grey and Green Infrastructures', Landscape Review, 17(2), pp. 1-4. 